\title{
MÚSICA PARA MATAR O TEMPO INTERVALO, SUSPENSÃO E IMERSÃO
}

Rose Satiko Gitirana Hikiji

\begin{abstract}
Olhe, essas pecinhas insignificantes duram sete minutos, em média, não é? E esses sete minutos têm alguma coisa em particular, têm princípio e têm fim, destacamse e são, de certo modo, preservados da ameaça de se perderem sem mais nem menos na monotonia geral. Além disso, são ainda muitas vezes subdivididos pelas partes da peça, e estas, por sua vez, se compõem de compassos, de maneira que sempre acontece alguma coisa e cada instante recebe um certo sentido, ao qual se pode agarrar, ao passo que normalmente [...] Não sei se me expressei... (Joachim, personagem d' A montanha mágica, de Thomas Mann)
\end{abstract}

Ambas [a música e a mitologia] são, na verdade, máquinas de suprimir o tempo. Abaixo dos sons e dos ritmos, a música opera sobre um terreno bruto, que é o tempo fisiológico do ouvinte. [...] ao ouvirmos música, e enquanto a escutamos, atingimos uma espécie de imortalidade.

(Claude Lévi-Strauss, em O cru e o cozido)

[a música] ajuda a matar o tempo.

(Jovem interno na Febem)

Ouvi esta última frase repetidas vezes. "Matar o tempo" era a resposta mais comum quando perguntava aos jovens alunos do projeto que pesquisava por que tinham decidido estudar música. A pesquisa em questão, para meu doutoramento em antropologia, teve como base as atividades do Projeto Guri, programa da Secretaria de Cultura do Estado de São Paulo de ensino musical por meio da formação de orquestras didáticas e corais, destinado principalmente a crianças de baixa renda ${ }^{1}$. "Fazer música para matar o tempo" era a justificativa que se repetia tanto entre internos que estudavam violino ou canto em um pólo do 
MÚSICA PARA MATAR O TEMPO - INTERVALO, SUSPENSÃO E IMERSÃO

Projeto Guri na Fundação para o Bem-Estar do Menor (Febem) quanto entre alunos de pólos abertos. Também pais e proponentes afirmavam a necessidade de "ocupar o tempo" das crianças e jovens, de "tirá-los da rua". A prática musical proposta pelo projeto estudado servia, a princípio, a esse propósito ocupacional. No entanto, a especificidade do tempo do fazer musical e das temporalidades vividas pelos jovens revelava-se mais complexa do que a perspectiva utilitária deixava entrever. Neste artigo, discuto as relações entre estas temporalidades e a experiência de suspensão temporal proporcionada pelo fazer musical.

\section{Tempo musical}

A música tem com o tempo relação bastante peculiar. Duração é uma de suas quatro propriedades fundamentais ${ }^{2}$. Na escrita musical ocidental, há figuras para indicar a duração de um som ou de sua ausência (pausa) em uma composição. Números são usados para indicar a divisão da música em "unidades de tempo". Em uma valsa, por exemplo, a música é dividida em compassos de três unidades de tempo, sendo a primeira, convencionalmente, a que é tocada com mais intensidade - TUM, tam, tam...

A música põe em suspensão o tempo cotidiano, ao dotar de conteúdo sonoro, sentido e ordem (o "princípio e fim" de Joachim), um determinado espaço de tempo.

Quando a música é escrita com gênio, todos os acontecimentos são cuidadosamente selecionados, a fim de construírem a subestrutura para relações excepcionalmente profundas. [...] Assim, embora por um breve espaço de tempo, alcançamos uma compreensão mais profunda do mundo (ou, pelo menos, de uma pequena parte dele) [...] É por esse motivo que a música pode ser transcendente. Durante alguns momentos, ela nos torna maiores do que realmente somos, e ao mundo, mais ordenado do que ele realmente é (Jourdain 1998:416, ênfase minha).

O tempo da escuta musical difere do tempo da leitura ou da observação de uma obra de arte. Edward Said tece uma comparação: "na literatura e na pintura, o tempo não está sempre avançando: você pode parar, voltar atrás, ler, reler [...] não se trata de uma situação tão imperiosa como a do concerto, que [...] dita a lógica de ir do começo ao fim" (Barenboim e Said 2003:45). O pianista e maestro Daniel Barenboim, interlocutor de Said nesse diálogo sobre música e sociedade, destaca no universo da música de concerto sua característica única de "irrepetibilidade". A música "em concerto" é única. Pode ser gravada e reproduzida, mas a gravação não possibilita as emoções ímpares 
sentidas pelo público que acompanha o espetáculo. Para Barenboim, nada na vida se compara à "empolgação de conseguir realmente viver uma determinada peça do começo ao fim sem interrupção, sem sair dela" (2003:51).

Lévi-Strauss (s/d:240-244), ao analisar a estrutura dos mitos, percebe que estes operam em um sistema de referência temporal de duas dimensões: esse sistema é ao mesmo tempo diacrônico e sincrônico, reunindo as propriedades da "língua" e da "fala". A partir de Saussure, Lévi-Strauss argumenta que a língua pertence ao domínio do tempo reversível, e a fala, ao domínio do tempo irreversível. O mito combinaria as propriedades desses dois domínios: por um lado, os acontecimentos aos quais diz respeito seriam sempre acontecimentos passados ("antes da criação do mundo"), por outro, esses acontecimentos formariam uma "estrutura permanente", que se relaciona com passado, presente e futuro. LéviStrauss percebe na análise de uma partitura musical um modelo para a análise mítica, uma vez que a partitura pode ser lida na horizontal e na vertical, ou seja, em diacronia ou sincronia, em melodia ou harmonia. A música, portanto, compartilha com o mito sua característica temporal de simultânea sincronia e diacronia: na partitura, a música revela-se em sua estrutura, é reversível; em "concerto", como notou Barenboim, faz-se irreversível, e única, portanto ${ }^{3}$.

$\mathrm{Na}$ obra em que mais se aproxima do universo musical, O cru e o cozido, Lévi-Strauss aprofunda a comparação entre mito e música. Afirma que ambos transcendem o plano da linguagem articulada, apesar de necessitarem, como aquela, de uma dimensão temporal para se manifestarem: "Mas essa relação com o tempo é de natureza muito particular: tudo se passa como se a música e a mitologia só precisassem do tempo para infligir-lhe um desmentido". Daí a definição do mito e da música como "máquinas de suprimir o tempo", que nos colocam, como ouvintes, em uma condição temporária de imortalidade (Lévi-Strauss 1991:24).

A música, enfim, domestica o tempo e os sons, implica síntese e ordem. Claude Debussy teria comentado, certa vez, que havia mais a ganhar observando o sol nascer do que ouvindo a Sinfonia Pastoral de Beethoven. "Felizmente, sua convicção não o impediu de compor", argumenta Pierre Jourdain. Os amanheceres são habitualmente suaves e os seres humanos, em geral, pouco reagem a amanheceres, mesmo quando são extraordinários. "Em contraste, a música, e a arte em geral, proporcionam à mente experiência cuidadosamente ordenada — um amanhecer perfeito para sempre [...]Um bando de pássaros piando forte produz todas as notas isoladas de uma sinfonia, mas não numa hierarquia ordenada de agrupamentos" (Jourdain 1998:414-415). O nascer do sol e a Pastoral remetem, em síntese, à natureza e à cultura, e à passagem explicitada por Lévi-Strauss (1991:30): "a natureza produz ruídos, e não sons musicais, que são monopólio da cultura enquanto criadora dos instrumentos e do canto". 
Um bom exemplo do molde cultural da música é a existência das escalas, "paradigmas construídos artificialmente pelas culturas" (Wisnik 1999:71). Estas últimas representam uma "grande diversidade das culturas musicais: que som interditar ou escolher!", nas palavras de Miranda (2001:23). A possibilidade de extrair, eleger e ordenar ou silenciar certos sons, "a partir do estoque polimorfo dos ruídos da natureza" (2001:23) é sem dúvida uma das bases da diversidade cultural no que diz respeito à música.

Entretanto, insiste Lévi-Strauss (1991:25), a música é cultura e natureza. Além de operar no molde cultural, opera também no molde natural ao dirigir-se ao tempo psicológico, fisiológico e "até visceral" do ouvinte: "periodicidade das ondas cerebrais e dos ritmos orgânicos, capacidade da memória e capacidade de atenção". É a partir desta dupla ancoragem - natureza e cultura - e da dupla dimensão temporal presente no mito e na música que Lévi-Strauss derivará seu potencial extraordinário de agir sobre "o espírito e os sentidos", de mover "idéias e emoções" (1991:35).

A conexão entre música, tempo e corpo pode ser observada quando analisamos uma categoria fundamental à leitura da música ocidental tonal: o "andamento". É por meio de indicações como allegro, andante, lento etc. na partitura que o músico saberá com que velocidade e intenção deve ser tocada determinada composição. Wisnik lembra que as categorias de andamento são fundamentadas em disposições físicas e psicológicas. O fato de a terminologia tradicional indicar como "andante" a medida média de ritmo de uma música é sintomático da aproximação entre tempo musical e tempo corporal, entre pulsação rítmica e pulso/ coração. "Os indianos usam o batimento do coração ou o piscar do olho como referência", um teórico do século XVII sugeria que "o padrão regular de todos os andamentos, seria 'o pulso de uma pessoa de bom humor, fogosa e leve, à tarde'!" (Wisnik 1999:19). A aproximação entre corpo, tempo e música pode ser ainda mais radical: "O feto cresce no útero ao som do coração da mãe", "o ritmo está na base de todas as percepções". Daí, pode-se intuir o "grande poder de atuação [da música] sobre o corpo e a mente, sobre a consciência e o inconsciente, numa espécie de eficácia simbólica" (1999:30).

"Eu gosto mesmo é de concerto pesado, que faz esquentar o sangue." A frase de um jovem interno na Febem ecoa a reflexão sobre a relação entre música e fisiologia. Quando questionei o rapaz, estudante de violino havia dois anos, sobre o que era "concerto pesado" (sobretudo por conhecer o repertório das orquestras do Projeto Guri e não identificar, ali, nada supostamente "pesado"), ele me respondeu: "qualquer coisa que toque rápido e faça esquentar o sangue". Os exemplos que apontou em tal repertório - "Brincando na Neve", "Minueto" - estavam distantes do que eu entendia como "pesado", um show de heavy metal, por exemplo, ou, no mínimo, um concerto grosso $0^{4}$. No contexto da internação, no 
entanto, usar o corpo para fazer música, subir em um palco e ser aplaudido pode, efetivamente, esquentar o sangue... A relação entre o tempo da prática musical e as temporalidades vividas pelos jovens será desenvolvida a seguir.

\section{0 tempo perigoso}

Cabeça parada, oficina do diabo

Este dito popular - comum nas prisões (para adultos ou para jovens) - poderia ser o slogan dos projetos voltados para a infância e a juventude no país. O fato é que, no universo destes projetos, é consenso entre pais, alunos, proponentes, professores e formadores de opinião a necessidade da ocupação do "tempo ocioso" das crianças e dos jovens. O mesmo vale para os jovens internados: a ocupação do tempo é a idéia que fundamenta a política institucional da Febem em São Paulo, ao menos desde as grandes rebeliões de $1999^{5}$.

Tais pensamentos têm como princípio a noção de que o tempo "ocioso" é um tempo perigoso. É preciso, afirma-se, ocupar o tempo. Fato curioso é que tal necessidade seja colocada em contextos muito diversos: na Febem, na periferia de São Paulo ou de outras capitais, nos centros urbanos em geral, inclusive entre famílias de classe média ou alta. $\mathrm{O}$ "perigo" do tempo livre une crianças e jovens separados pela desigualdade social e cultural ímpar em nosso país.

Uso o termo "tempo livre" aqui no sentido de tempo liberado da escola, tal como surge na fala dos sujeitos pesquisados. Na literatura sobre lazer, a noção de tempo livre é geralmente construída em oposição ao universo do trabalho. Alguns autores, no entanto, advertem que o tempo resultante da diminuição da jornada de trabalho ${ }^{6}$ é "tempo liberado", não "tempo livre". Excetuadas as horas gastas com transporte, cuidados obrigatórios com a casa e a família, restaria o "tempo livre" que, na acepção de Erich Fromm, é ainda diferenciado quando é um "tempo livre de" (obrigações) ou um "tempo livre para" (a liberdade) (apud Waichman 2001:35).

É interessante notar que, na história do pensamento ocidental, entre os gregos, o ócio já tenha sido visto como ideal de vida

No grego sckolé (ócio) opõe-se a asckolé, que tem a conotação de servidão. Curiosamente, do termo sckolé deriva a palavra escola. Sckolé era o desenvolvimento dos valores supremos da cultura grega, que permitiam a contemplação da sabedoria [...] Tinham tempo para isso aqueles que, com o trabalho dos escravos, possuíam a riqueza material possibilitadora de um tempo para o ócio. E esse 
tempo livre era, justamente, o oposto do tempo para não fazer nada. Era o tempo do saber não utilitário [...] O ócio é um ideal de vida, portanto, um fim; ao passo que o trabalho, que o possibilita, é um meio (Waichman 2001:44).

É dos romanos a concepção do ócio como um tempo de não-trabalho, um complemento ao trabalho, que "permite recuperar-se para ele" (Waichman 2001:45). Já a atribuição de valores negativos ao ócio tem origem a partir da Revolução Industrial, quando o ócio e o tempo livre são incompatíveis com a geração de riquezas e característicos de "classes parasitárias contrárias ao progresso social" (2001:45). Têm origem aí as noções de que "tempo é dinheiro" e de que "o ócio é a mãe de todos os vícios".

O século XX permite o desenvolvimento da concepção do ócio como "prêmio", "conquista do esforço de trabalho realizado" (Loewenstein apud Waichman 2001:52) e, conseqüentemente, "tempo disponível para o consumo" (Mead apud Waichman 2001:52). Nos estudos sobre o lazer desenvolvidos ao longo do século $\mathrm{XX}$, discutem-se as naturezas subjetivas ou objetivas do ócio. Para Munné (apud Waichman 2001:86), o ócio é dotado de subjetividade, uma vez que implica o uso do tempo pelo indivíduo para desenvolver as suas necessidades (fazer "o que queremos"). Para Dumazedier (apud Waichman 2001:87), o ócio é concebido com base na análise objetiva das atividades realizadas: é, portanto, um conjunto de ocupações consentidas visando descanso, diversão e desenvolvimento.

Pablo Waichman, nesse levantamento de análises sobre o lazer, aponta como tendência na teoria sobre o lazer do fim do século XX a discussão acerca da transformação do ócio em efetivo "tempo livre", no sentido de "tempo em que o indivíduo desenvolve suas necessidades, quando se autocondiciona" (2001:85). Em sua acepção, o "tempo livre" corresponderia à "liberdade plena", que vai além da "liberdade de" e alcança a "liberdade para": "O tempo livre será tal quando significar a liberdade no tempo e não do tempo" (2001:96).

Victor Turner desenvolve reflexão neste sentido. Dentre várias analogias entre sociedades de pequena e grande escala, Turner pensou a relação entre situações liminares de sociedades do primeiro tipo e os fenômenos relacionados ao lazer nas sociedades complexas, aos quais o autor chamou de liminóides. Em From ritual to theatre (1982), Turner procura mostrar que os gêneros de lazer industrial - como teatro, poesia, balé, romance, filme, esporte, rock, música clássica, arte etc. - são, de certa forma, correspondentes aos processos liminares que implicam o uso de máscaras, o disfarce, a inversão e a paródia da realidade profana em mitos e histórias. A principal semelhança entre os processos em questão é que ambos são reflexivos, estimulam os que neles estão envolvidos a pensar a sociedade. 
Turner (1982:36-37) ressalta o caráter libertário dos gêneros de lazer. Para o autor, o lazer é um fenômeno "tipicamente urbano", que pressupõe o trabalho. Durante o tempo do lazer, fica-se livre de uma série de obrigações institucionais e dos ritmos cronologicamente regulados da fábrica e do escritório; tem-se uma chance de recuperar e curtir os ritmos biológicos e naturais. Lazer é também liberdade de entrar em (e gerar) novos mundos simbólicos de entretenimento, esportes, jogos e diversões de todos os tipos. Liberdade de transcender as limitações sociais estruturais, liberdade de jogar com idéias, fantasias, palavras, pintura, relações sociais. Para Turner, o lazer é potencialmente capaz de liberar poderes criativos, individuais ou comuns, para criticar os valores dominantes da estrutura social. A prática musical está entre as atividades consideradas por Turner como liminóides.

Entre as concepções de tempo perigoso e tempo para a liberdade, há um trajeto a ser percorrido. Cabe investigar o porquê do medo do ócio, os sentidos da ocupação do tempo com música e as possibilidades do tempo musical como um tempo para a liberdade.

\section{A casa e a rua (revisitadas)}

Os que não estão aqui dentro, quando não estão na atividade, estão na rua. Então você está tirando da rua através da música.

(Ana Laís Parro dos Santos, coordenadora do pólo POF Morumbi do Projeto Guri)

A gente é dona-de-casa, não é fácil ficar três dias fora. Mas tem que tirar da rua. Na rua, se aprende cada coisa...

Eu tenho quatro meninos (de dezessete, oito, cinco anos e um de onze meses) e uma menina. Ela tem vontade de fazer as coisas. Os meninos não fazem curso. Ficam em casa. Na rua não vão, só na porta de casa com os colegas deles. A menina, antes daqui, só ficava em casa. Porque na rua eu não deixo brincar, não deixo sair, nada. (Mães de alunas do pólo Mazzaropi do Guri)

"A duração se exprime sempre em extensão. Os termos que designam o tempo são tomados à linguagem do espaço. Quando invocamos o tempo, é o espaço que responde ao chamado". A análise na qual Bergson (apud Silva, 2000:87) elabora a relação entre tempo e espaço é observada nas diversas falas dos atores pesquisados: o tempo "ocioso" é relacionado à rua e a seu "perigo". "Ocupar o tempo" é sinônimo de "tirar as crianças da rua".

Roberto DaMatta (1991:61) enfatizou a passagem "dramática" entre casa e rua, sendo esta última o espaço do perigo, das relações impessoais e desumanas. 
A rua é local de "indesejável individualização, de luta e de malandragem". A situação atual das metrópoles brasileiras tinge com cores ainda mais dramáticas esta caracterização da rua: é o domínio do crime organizado, é palco de uma violência cada vez mais efetiva, que atinge adolescentes cada vez mais novos.

A ocupação do tempo fora da escola é um dos principais objetivos dos projetos governamentais ou não-governamentais destinados aos "jovens em situação de risco"7. Os pais de alunos não medem esforços em sua maratona para manter os filhos ocupados. Mesmo alguns jovens associam o espaço da rua a aspectos negativos, como o crime e a violência, embora, para eles, a casa não seja tampouco lugar valorizado. Para várias das crianças e jovens entrevistados, ficar em casa é sinônimo de ter de ajudar a mãe a lavar roupa, lavar louça, fazer comida.

O tempo que não é dedicado às tarefas domésticas e à "lição de casa", é geralmente ocupado pela televisão. Várias crianças e jovens não podem sair de casa (ou do prédio) para brincar. Para estes, a rua não é uma opção (os pais não deixam, eles não querem ir para a rua). Alguns alunos, quando questionados se a música era melhor que a escola, responderam que ambos são melhores do que ficar em casa.

É interessante notar, com DaMatta, que casa e rua não são espaços de significação estanque. Uma característica importante do Projeto Guri é levar as crianças e jovens participantes a vários espaços da cidade, permitindo uma efetiva ampliação de horizontes; é gerar um processo de saída da casa, de ocupação dos espaços públicos. Nas falas dos jovens é destacado, no entanto, o fato de "sentir-se em casa" nesses espaços (nos pólos onde ensaiam, nos anfiteatros em que se apresentam). Relações de solidariedade e confiança são responsáveis pela familiarização com espaços públicos antes marcados pela impessoalidade.

José Guilherme Magnani construiu a categoria pedaço para descrever a relação com o espaço urbano, intermediária entre o mundo da casa e o da rua. O pedaço é um espaço onde são construídas "lealdades, códigos compartilhados, pertencimentos". O pedaço implica uma rede de relações "que combina laços de parentesco, vizinhança, procedência, vínculos definidos por participação em atividades comunitárias e desportivas etc." (1992:192-193).

A participação em um projeto como o Guri corresponde, efetivamente, à inserção da criança ou jovem em um pedaço, no qual antigos vizinhos e novos amigos passam a constituir uma "família"8. O tempo despendido nas atividades do projeto é um dos fatores que contribuem para que, além do aprendizado musical, sejam construídos vínculos pessoais e grupais que conferem a um espaço público qualidades próximas do universo da casa.

Tipicamente, o participante do Guri vai ao pólo duas vezes por semana, no mínimo. Nestes dias, passa toda a tarde em atividades como aula em grupo, ensaio de orquestra, coral ou camerata e prática do instrumento. Nos intervalos 
entre as atividades, encontram-se nos corredores para conversar, às vezes para comer. Muitos vão ou voltam juntos para casa. São vizinhos que chegaram ao Guri por indicação de outros vizinhos. Os mais velhos estendem a convivência para espaços exteriores ao da prática musical. Saem juntos nos fins de semana, vão a museus, shows. Alguns freqüentam ou passam a freqüentar a mesma igreja. Alessandra, aluna de violino desde o início do Guri, contou-me também que mesmo aqueles que saem do Projeto continuam em contato: combinam algum encontro, avisam uns aos outros quando vai haver algum concurso, uma oportunidade de emprego. São vínculos que perduram.

\section{Música de rua}

Perguntei para os garotos se eles faziam o coral. Eles responderam negativamente. Os rappers completaram: "eles fazem música de rua".

(Trecho do caderno de campo, referente à pesquisa na Febem).

Um parêntese se faz necessário nessa reflexão sobre a rua e o tempo. Diferentemente do tempo ocioso - nunca desejado - a rua é valorizada em algumas formas de sociabilidade juvenil na periferia. Em ao menos um contexto - o da internação - a rua é, obviamente, sinônimo de liberdade e, em alguns casos, de uma cultura própria, o rap. Esse estilo musical, caracterizado por canções de denúncia social mais faladas que cantadas - e parte de um movimento mais amplo, o hip hop, vem ganhando, desde a década de 80, um público bastante relevante, sobretudo na periferia paulista.

Pedro Guasco (2001:118), em sua dissertação sobre o rap paulista, afirma que, no discurso dos rappers, "a rua aparece como espaço de cultura e metáfora da sociedade". Para os rappers, a rua é um "lugar da experiência diante do social", "um tipo de conhecimento" (2001:120). Marilia Sposito (1994:167), apesar de notar as "alterações no padrão das relações sociais que ocorrem nas ruas e bairros da cidade" — em virtude do crescimento do crime, do tráfico de drogas e da corrupção policial - percebe a rua, na cultura dos rappers, como espaço de sociabilidade que se sobrepõe aos locais socializadores por excelência, como a escola, por exemplo.

No trecho do caderno de campo que reproduzi acima, está registrado um dos poucos momentos da pesquisa em que o tema da cultura de rua surgiu na fala dos sujeitos pesquisados - e, mais importante, como contraposição à produção musical realizada no Projeto - "eles não são do coral, fazem música de rua". No entanto, cabe notar que a fala não é de internos e participantes do projeto, mas de rappers profissionais que realizavam, naquele 
momento, um projeto chamado "Realidade" em parceria com o setor de Projetos Especiais da Febem. O projeto consistia na seleção de jovens que cantassem ou compusessem raps, para participar da gravação de uma das faixas do CD do grupo Jigaboo. Os integrantes do grupo iam à Febem ouvir os raps compostos pelos jovens e selecionar os participantes do $\mathrm{CD}^{9}$.

Para os participantes do Guri, tal separação entre a música de rua e a música aprendida no Projeto não parecia tão evidente. Tanto que membros do coral, ensaiados pelo regente do Guri, participaram da gravação do CD, cantando o refrão da música em um arranjo para três vozes. Ao menos no plano musical, foram encontradas soluções de aproximação entre universos sonoros e sociais diferentes, resultando em um rap com interferências de técnica vocal e de composição eruditas.

O fato é que o universo do rap - e sua valorização da rua como espaço de cultura — não é o único referencial dos jovens da periferia paulista. Dentre os jovens que pesquisei, o rap tinha mais adeptos no pólo Febem do Projeto Guri. Nos demais pólos - Mazzaropi, POF e São Remo ${ }^{10}$ — as preferências musicais dividiam-se entre o samba, o pagode, o rock e o pop internacional.

Importa notar que, diferentemente dos rappers profissionais que faziam questão de contrapor sua música "de rua" à música feita no Guri, os participantes do projeto não consideram que aprender música "na escola" interfira no resultado final de sua atuação como músico nas ruas. Conheci jovens pagodeiros que, a despeito de já atuarem profissionalmente em suas comunidades, faziam canto no Guri para aperfeiçoar sua técnica vocal. Outros, também pagodeiros, estudavam percussão e tocavam nas orquestras do projeto, onde acreditavam estar aprendendo novos ritmos (frevo, maracatu, samba) com os quais poderiam incrementar suas apresentações nos bares da comunidade. Jovens estudantes de violão, que aprendiam a dedilhar melodias clássicas nas aulas do Guri, diziam que, depois das aulas, havia ficado mais fácil tocar seus rocks preferidos, inclusive os trechos solos que tocavam "de ouvido".

Fechando o parêntese: registrei, em poucas linhas, a existência, no universo pesquisado, de um campo no qual a rua não é associada apenas ao perigo, mas também à possibilidade de produção cultural. Mais ou menos distantes do universo do rap, os jovens que conheci no Guri, ao fugirem dos perigos do tempo ocioso e da rua, encontraram em um espaço fora de suas casas, novas possibilidades de sociabilidade e novos acessos para as ruas e alguns de seus espaços. Em vez de fecharem-se em suas casas, esses jovens percorrem trajetos mais ou menos longos, de ônibus, de carro ou a pé, para ir ao pólo, duas vezes por semana - ou até mais, conforme o calendário de apresentações. O que procuro mostrar em meu trabalho é que, apesar de pontos de partida díspares — o "medo" da rua versus a "cultura de rua" — as práticas musicais no Guri 
ou nos "pedaços"11 dos rappers implicam a apropriação do espaço urbano, a ampliação de horizontes, o contato com a diferença. Os produtos culturais que resultam das práticas em questão revelam uma diversidade que é constitutiva da própria experiência de juventude nas periferias paulistas.

\section{Intervalo}

Como apontei no início deste artigo, o "matar o tempo" e o "tirar da rua" são as primeiras justificativas para a procura pelo fazer musical. Os proponentes de projetos de intervenção social para crianças e jovens de baixa renda também reconhecem como uma de suas funções, a "ocupacional". No entanto, a observação do cotidiano das atividades no projeto estudado revelava algumas especificidades dessa ocupação de tempo, a partir do tipo de atividade oferecida. O tempo da prática musical precisava ser analisado em densidade.

Mesmo antes de tocar violino, eu sempre estava com um walkman, música na cabeça. Música é tudo. Quando você está triste, você pára e escuta uma música para ver se melhora o ânimo. Quando tá meio chateada, escuta música. É fundamental pra todo mundo. Não tem aquele velho ditado que diz 'quem canta seus males espanta'? Eu levo bem a sério! (Tatiane Miê Hirano, 18, estudante de violino no pólo Mazzaropi havia três anos).

Tatiane lembra que se pára para escutar uma música. Música implica uma interrupção no fluxo da vida cotidiana. A pausa faz mudar o humor. A música altera ritmos, sensibilidades, sintonias. Proponho pensar a prática musical como intervalo, espaço de liminaridade e, eventualmente, de reflexividade. Antes de Victor Turner, Johan Huizinga experimentara esta abordagem em seu tratado sobre o jogo. Huizinga diferencia as atividades lúdicas — entre as quais inclui a música — da vida ordinária: o jogo é intermezzo, descanso, "um intervalo em nossa vida cotidiana" (2000:12). Daí também a afinidade entre jogo e música: ambos situam-se "fora da sensatez da vida prática, nada têm a ver com a necessidade ou a utilidade, com o dever ou com a verdade" (2000:177).

A matriz da leitura de Huizinga é aristotélica. O autor retomará o filósofo grego e sua reflexão sobre a música. Apesar de ressaltar que música, para os gregos, abarca mais do que o que nós entendemos hoje como tal — incluindo também a dança, as artes e demais habilidades presididas por Apolo e pelas Musas - Huizinga destaca os fundamentos da definição de Aristóteles sobre a natureza da música e os utiliza na reflexão acerca das esferas lúdicas em nossa sociedade. 
Para Aristóteles, a música, como o sono e a bebida, não é em si mesma coisa importante ou séria, mas agradável e capaz de "afastar as preocupações" (apud Huizinga 2000:180). Pode, no entanto, conduzir à virtude, na medida em que, "tal como a ginástica, é capaz de exercitar o corpo, alimenta uma certa ética e nos permite gozar as coisas de maneira adequada" (apud Huizinga 2000:180). A música pode, ainda, contribuir "para a recreação mental e para a aquisição de conhecimentos". Dentre estas duas últimas "funções" da música descritas por Aristóteles, Huizinga destaca a interpretação do termo "recreação mental", que poderia ser traduzido também como o "passar" ou o "gastar" do tempo. "Traduzi-la por 'passatempo' só é aceitável quando se tem perante o trabalho e o ócio a mesma atitude de Aristóteles" (Huizinga 2000:180), ou seja, quando se considera o ócio o princípio do universo, coisa preferível ao trabalho, e, sem dúvida, o fim de todo trabalho.

Assim, na leitura aristotélica, a música é ora instrumento de relaxamento e torpor (como o vinho), ora meio de exercício do corpo e da virtude do ouvinte. É, entretanto, sempre passatempo, bem entendida a importância, para os gregos, desse tempo a ser "gasto", o ócio.

Huizinga, com Aristóteles, percebe o trânsito das atividades lúdicas (como a música ou o jogo) entre o intervalo — o extraordinário - e a onipresença: "Todavia, em sua qualidade de distensão regularmente verificada, ele [o jogo] se torna um acompanhamento, um complemento e, em última análise, uma parte integrante da vida em geral" (2000:12). Na fala dos jovens que pesquiso, tal trânsito é percebido no modo como descrevem os significados do fazer musical: ora ele é um "matar tempo", ora representa "tudo" em suas vidas. Jovens que tinham começado a tocar para "matar o tempo" me contavam que, "com o tempo", passaram a gostar do aprendizado e, por fim, não conseguiam mais imaginar suas vidas sem a prática musical.

Importante fator que possibilita esse trânsito é a qualidade do jogo — e da música — de induzir à imersão. O jogo é dotado de intensidade, de fascínio, de uma "capacidade de excitar" — sua característica primordial, de acordo com Huizinga (2000:5). É ainda "atividade livre, conscientemente tomada como 'não-séria' e exterior à vida habitual, mas ao mesmo tempo capaz de absorver o jogador de maneira intensa e total" (2000:16).

Em geral, a experiência de imersão não é solitária. Como nos lembra DaMatta, o momento extraordinário, na era do individualismo, nos transforma em seres coletivos: "somos dupla ou somos torcida, partido, público, multidão" (1991:45). Os exemplos são, quase todos, retirados da esfera do lúdico: jogo (dupla, torcida, multidão), música/ espetáculo (público, multidão). Tal caráter coletivo vivenciado na atividade lúdica é destacado por Huizinga (2000:455): "a sensação de ter tratamento exclusivo, estar dedicado em conjunto a algo importante, de diferenciar-se 
em comum de outros [...] exerce um efeito mágico que ultrapassa a duração do jogo". Interessante notar que este autor destaca a possibilidade de o efeito "mágico" da experiência coletiva perdurar além do tempo do jogo. No caso da prática musical em conjunto aqui estudada, é justamente essa possibilidade, uma de suas características mais importantes no que diz respeito às suas conseqüências — não apenas musicais — na vida dos jovens participantes.

A imersão é marcada também por mudanças na concepção de tempo: em competições, "segundos valem ouro"; no cinema, "momentos produzem emoção" (DaMatta 1991:42), a passagem de dias, meses ou anos é representada em segundos. O tempo [da execução, de estudo] musical pode ser medido em horas - minutos de estudo, de aula - ou sentido, por exemplo, no corpo que aquece, no corpo que cansa. O tempo da escuta musical é percebido de formas diversas conforme o envolvimento daquele que é atingido pela música. Um concerto pode ser longo, demorado e até interminável quando não se está envolvido; é veloz, intenso, "passa" rápido para aquele que imergiu.

A prática musical proposta no Guri demanda alguma disciplina e dedicação de tempo ao estudo. O Projeto baseia-se no ensino de instrumentos de orquestra em aulas coletivas e na participação dos alunos nos grupos musicais do pólo, como orquestras, cameratas de violões e corais. O repertório é composto por arranjos simplificados para peças eruditas e populares.

Por não se propor a formar músicos, no sentido estrito da palavra, o projeto não exige a quantidade de horas de estudo que normalmente se exigiria de estudantes com objetivo de profissionalização. O maestro que rege a orquestra do Mazzaropi disse-me, certa vez, que o ideal seria que todos os alunos estudassem umas três ou quatro horas por dia mas, não sendo possível tal dedicação, esperava-se um estudo de pelo menos uma hora diária.

No Guri, nem todos os alunos possuem seu próprio instrumento. Os que se enquadram neste caso têm a permissão de freqüentar o pólo, fora do horário de sua aula, para estudar. Tal dedicação é, no entanto, um tanto complicada: implica gastar mais dinheiro com transporte, ir ao pólo mais um dia na semana etc. ${ }^{12}$. Dentre aqueles que possuem o próprio instrumento, conheci desde os que diziam estudar por cerca de quatro horas diárias até aqueles que se esforçavam em estudar pelo menos 15 minutos, conforme orientação do professor. Em alguns casos, o tempo e o espaço de estudo foram lentamente negociados com a própria família (que precisa, muitas vezes, dividir os poucos cômodos da casa com o "barulho" de um instrumento - invariavelmente mal tocado, a princípio). Em outros, a prática do instrumento em casa passou a configurar um espaço-tempo próprio ao jovem. Alguns estudantes de violão contaram-me que a atividade de que realmente gostavam era a de tocar sozinhos, em seus quartos, durante horas, após a escola. 
A observação da dinâmica das aulas — mesmo se considerada somente a aula conjunta de música ou o ensaio - revela que o aprendizado musical implica uma dedicação efetiva de tempo e energia. Sendo uma atividade opcional e livre, tal dedicação não ocorreria se não houvesse um envolvimento real dos alunos com o aprendizado. Esse envolvimento é construído de diversas formas. Há a atração pela novidade: conseguir extrair sons de instrumentos pouco conhecidos, como o violino ou o clarinete, já é, por si só, um desafio estimulante. Há os avanços perceptíveis a cada aula: os sons começam a ficar mais limpos, novas notas são aprendidas a todo o momento, as primeiras melodias são obtidas já após algumas aulas. Há o efeito do conjunto: tocar com outras pessoas, mesmo que a maioria iniciante, produz uma sonoridade cheia, da qual o aluno e seu instrumento passam a fazer parte. A orquestra precisa do músico como este precisa dela para ser ouvido. Há sempre um objetivo a ser alcançado em uma aula ou no estudo privado: ler uma nova música, ensaiar um repertório, aprender um movimento. As inúmeras repetições nunca são em vão. Ao final da atividade (aula, estudo, ensaio), algum resultado foi obtido, e ele é, em geral, perceptível (sobretudo, audível) para o estudante. Há, principalmente, o prazer de se perceber fazendo música, "criando o belo" - e isso é possível desde o primeiro dia de aula, até o fim da vida do músico.

No pólo Mazzaropi, conheci estudantes de 10, 12 anos que me disseram terem se tornado mais organizadas após seu ingresso no Guri. "A gente aprende a administrar melhor o nosso tempo", dizia uma menina. Para ela, não estava mais em questão o tempo ocioso: o dia estava repleto de atividades que precisavam ser realizadas com algum método. No mesmo pólo, vários jovens me narraram as mudanças em seu cotidiano, a partir das aulas no Guri: os dias no pólo ou o estudo em casa implicaram a diminuição das horas na frente da televisão e uma melhor divisão de suas atividades no dia-a-dia.

O que, no entanto, mais me impressionava nas atividades dos diversos pólos era o tempo que os alunos - jovens e crianças de até sete, oito anos - passavam tocando ou cantando juntos. Aulas e ensaios longos, de até quatro horas, eram comuns em alguns pólos, como no da Febem. Em momentos que precediam as apresentações, os alunos passavam boa parte do tempo treinando uma música ou uma seqüência, ensaiando com o maestro o que seria apresentado. Não observei muitas expressões de desânimo ou desinteresse. Mesmo sem a presença do professor ou do maestro, os alunos discutiam partes da execução entre si, explicavam uns aos outros sobre seu instrumento, concentravam-se em fazer música.

Schechner, ao refletir sobre a performance, mostra que essa, ao promover a desconstrução e a reconstrução do corpo, marca as experiências de vida 
dos performers ${ }^{13}$. Por isso, não pensa a performance como interrupção da vida cotidiana, mas sim como seu prolongamento: "Considere o jogo como o contínuo fundamental e sempre presente da experiência, como diz a teoria maya-lila" (Schechner 1995:42, tradução minha).

Imersão e envolvimento. Estas características do fazer musical - e do jogo, em geral, para seguir Huizinga - são as principais responsáveis por permitir que o "tempo para a música", inicialmente um intervalo, transborde para o resto da vida cotidiana, passando a determinar o ritmo dos dias, a preencher momentos antes vazios, a solicitar cada vez mais dedicação, a fazer da música "tudo" na vida de uma criança ou de um jovem.

A especificidade de uma das situações que estudei - a prática musical entre jovens internos em uma instituição - será analisada mais detidamente, por revelar algumas peculiaridades da relação entre o tempo da prática musical e a temporalidade dos jovens aprendizes. A internação é uma situação limite que, no entanto, muito nos diz sobre a condição do jovem de baixa renda em São Paulo, de seus desejos, expectativas e falta de opções. O que nessa instituição observei tem muito de particular, mas permite vislumbrar como a prática musical pode atuar na construção de regularidades, expectativas, ritmos e pausas nas vidas dos jovens, estejam estes livres ou em situação de reclusão.

\section{Tempo em suspensão - etnografia do ruído}

A instituição na qual pude observar a relação entre a prática musical e a temporalidade específica do jovem em situação de internação é o complexo do Tatuapé da Febem. Criada na década de 70, durante o período militar, no âmbito de um projeto que vinculava o problema do menor à esfera da segurança nacional, essa instituição abrigava, em 1999, quando iniciei a pesquisa, aproximadamente 1600 internos cuja idade variava dos 12 aos 21 anos, todos do sexo masculino. Os adolescentes eram divididos em 14 Unidades Educacionais (UEs) — hoje chamadas Unidades de Internação (UIs) — supostamente de acordo com faixa etária e a gravidade dos atos infracionais cometidos.

No pólo Febem, o Projeto Guri teve início em julho de 1996, atendendo a setenta meninos. Esse foi o segundo pólo do Guri a ser criado e sempre obteve muito destaque na mídia em função de suas peculiaridades: era o único a ensinar, nos termos da cobertura midiática, "música de orquestra" para "menores infratores". Mesmo quando o Guri já contava com mais de vinte pólos em todo o estado, a imprensa sempre destacou as atividades do pólo Febem, causando até mesmo a confusão de todos os alunos com "internos da Febem", fato que causava descontentamento entre alunos de pólos destinados à população em geral. 
Entre 1996 e 2000, cerca de mil adolescentes passaram pelo pólo Febem; em abril de 2000, a Secretaria de Cultura suspendeu as atividades na instituição ${ }^{14}$; em 2002, algumas atividades do Guri foram retomadas, sendo realizadas no interior das Unidades Educacionais e também em outros pólos da Febem, como o internato feminino do Brás. No fim de 2003, em meio à discussão sobre a diminuição da idade penal e aos projetos do governador Geraldo Alckmin de aumento do tempo de reclusão de jovens envolvidos em crimes violentos, o governo do estado anunciou a extensão das atividades do Projeto Guri para todas as setenta unidades da Febem.

\section{Passatempo, fuga, subversão}

Esta não é minha primeira passagem.

Estudar música ajuda a passar o tempo.

(Frases comuns entre os internos da Febem)

O adolescente que chega à Febem sabe que está lá "de passagem". Uma característica da passagem é o redimensionamento do espaço e do tempo. A instituição "substitui" a casa e a rua e dita o ritmo diário dos internos. Este é caracterizado por uma rotina pormenorizada, com regras que regem dos movimentos corporais às atividades cotidianas ${ }^{15}$.

$\mathrm{Na}$ época da pesquisa, os jovens dividiam o tempo vivido nas UEs entre momentos com atividades (escola, trabalho, faxina, banho e alimentação, por exemplo) e tempo ocioso ou, em suas palavras, "ficar no pátio". No pátio, geralmente, fica-se sentado; para levantar, ir ao banheiro ou fumar é preciso pedir permissão ${ }^{16}$. No pátio, "pesa a cadeia": o "pátio" faz pensar no tempo não vivido - em tudo que está do outro lado das grades institucionais ou, nas palavras dos jovens, no "mundão". O pátio simboliza o máximo controle institucional e, do ponto de vista dos internos, sintetiza a situação de opressão ${ }^{17}$.

Kiko Goiffman, que analisou o cotidiano de prisões masculinas no Estado de São Paulo, percebe nesses contextos relação semelhante do preso com o ócio: "ao menos como discurso, [o ócio] é valorizado negativamente por todos os atores sociais envolvidos no cotidiano carcerário e também pela sociedade" (Goiffman 1998:115). Lembra o ditado "a cabeça do preso é a oficina do diabo" e diz: "ocioso, o preso dispõe de 'todo o tempo' para planejar fugas, revoltas" (1998:113). O tempo na prisão é encarado como "tempo perdido": "muitas vezes as tentativas de fuga são justificadas como uma busca do tempo perdido na prisão e a delação que leva o plano ao fracasso, um 'atraso'" (1998:114). 
Erving Goffman (1974) analisou as características desse "tempo perdido". Para o autor, o tempo nas prisões e hospitais para doentes mentais é algo que foi "posto entre parênteses". O internado tende a sentir-se "exilado da vida". Especialmente desmoralizadora é, para Goffman, a influência de uma "sentença indefinida", tal como ocorre na Febem ${ }^{18}$.

Entre os internados [...] existe um intenso sentimento de que o tempo passado no estabelecimento é tempo perdido, destruído ou tirado da vida da pessoa; é tempo que precisa ser 'apagado'; é algo que precisa ser 'cumprido', 'preenchido', ou 'arrastado' de alguma forma (Goffman 1974:64-65; ênfases minhas).Em entrevistas realizadas, em 2004, com funcionários do Projeto Guri, soube que a Febem criou uma política de "pátio zero". Após as rebeliões de 1999, o governo do estado determinou que os jovens tivessem todo o tempo ocupado com atividades esportivas, profissionalizantes ou de arte-educação. A instituição, frente à crise, percebe a ocupação do tempo vazio como uma possível solução. Os projetos, como o Guri, são chamados a atuar no preenchimento do tempo. Cabe questionar se o tempo preenchido pode compensar, de alguma maneira, o tempo perdido.

É comum destacar-se, nas análises sobre instituições totais, o papel da recreação / lazer como atividade para "passar o tempo". Goffman ressalta, inclusive, a importância atribuída às chamadas atividades de distração que, para ele, são "intencionalmente desprovidas de seriedade, mas suficientemente excitantes para tirar o participante de seu 'ensinamento', fazendo-o esquecer momentaneamente a sua situação real" (Goffman 1974:64-65; ênfases minhas). Os exemplos — jogos ao ar livre, bailes, participação em orquestras ou bandas de música, coral, aulas, ensino de arte - remetem imediatamente ao caso do Projeto Guri na Febem. Uma análise mais detida, entretanto, conduz ao questionamento dessa avaliação. Algumas situações vividas pelos participantes do Guri na Febem não permitem falar em esquecimento mas, como pretendo detalhar, em reflexividade.

O Guri era oferecido na Febem como uma das atividades educativas opcionais - apenas o ensino fundamental ou médio era obrigatório - que incluem também os cursos profissionalizantes (como marcenaria, computação, mecânica, culinária, tecelagem, horta), as atividades esportivas e as artísticas.

A participação nos cursos opcionais depende, em geral, da indicação da direção de cada unidade, que determina quais adolescentes poderão freqüentar as atividades, conforme avaliação de conduta e histórico individuais. Os internos que "causam problemas" na unidade (brigam, participam de tentativas de fuga, ou enfrentam funcionários) dificilmente participam dos cursos. Qualquer comportamento considerado indevido pode "retirar" os jovens das atividades. Esse fato, aliado às desinternações e fugas, faz com 
MÚSICA PARA MATAR O TEMPO - INTERVALO, SUSPENSÃO E IMERSÃO

que a freqüência nos cursos de maior duração seja bastante irregular. De certa forma, os internos também passam pelas atividades, muitas vezes, sem concluir o que seria um processo de aprendizado adequado.

Durante minha pesquisa na Febem, os alunos costumavam freqüentar duas aulas por semana do Guri (de instrumentos ou coral). As aulas eram em grupos, que variavam de dois a cerca de vintealunos. A entrada de um novo aluno acontecia quando surgiam vagas devido a desinternações ou fugas de alunos. A coordenação do projeto comunicava a abertura de vagas à direção das unidades (UEs) e ficava a critério destas a seleção dos internos que poderiam participar. Os critérios para a seleção eram os mesmos utilizados para os cursos profissionalizantes: a avaliação do comportamento era levada em conta.

Observei que alguns internos participavam de várias atividades, enquanto outros nunca saíam das unidades. A prática musical era também assimilada ao sistema de privilégios e castigos fundamentais à organização das instituições totais (cf. Goffman 1974).

Como nos demais pólos do Guri, na Febem, o contato do aluno com o instrumento era imediato, e rápido era também o acesso a um repertório erudito e popular com arranjos simplificados. Ao interno não eram, geralmente, oferecidas muitas opções de instrumentos. "Me perguntaram se eu queria aprender violino. Eu nem sabia direito o que era isso, mas fui. Pensei: é melhor que ficar na unidade", conta um jovem. Uma vez no projeto, o interno podia tentar mudar de curso, ou desistir. A taxa de desistência não era alta, mas a freqüência era muito variável em virtude de desinternações, fugas ou do próprio sistema de privilégios e castigos, que punia maus comportamentos com o corte do aluno das atividades do projeto.

A rapidez de acesso ao instrumento e a um repertório musical era justificada como estratégia pedagógica, embora eu tenha observado que, muitas vezes, a estratégia obedecia a interesses menos educativos do que políticos. O Projeto Guri era, em 1999, um dos produtos exibidos como "vitrine" da atuação do então Governo Covas na área da cultura - e continuou sendo no Governo Alckmin. Várias vezes, com o objetivo de preparar os alunos para uma audição pública institucional (que tem como objetivo apresentar o próprio projeto em um evento maior, como o Festival de Inverno de Campos de Jordão), havia ensaios e aulas extras, com uma carga horária bem maior que a normal. Passados os eventos, as aulas voltavam a seu ritmo normal.

Apesar do óbvio interesse político, a mudança no ritmo dos ensaios e aulas surtia efeito positivo para os alunos do projeto na Febem. No tempo marcado pela repetição, pelo ritmo ditado pela instituição, a intensificação das horas de aula e, sobretudo, de ensaios, correspondia a uma quebra na rotina. Como nota Goiffman (1998:116), se a redundância é regra no tempo da prisão, há "uma 
certa expectativa de instabilidade. A novidade e a quebra do tempo aparecem como promessa [...] rompem o ciclo dos dias que é retomado a seguir".

Também a percepção de que estavam trabalhando com algum objetivo - ensaiar um repertório para apresentação - estimulava os jovens, que manifestavam surpreendente interesse, concentração e vontade em aulas de até quatro horas de duração.

Quando questionava os jovens sobre o porquê de estudar música na Febem, as respostas sempre começavam com a justificativa da "fuga do pátio". Ficar na Unidade "parasitando", sem fazer nada, não ajuda a "matar o tempo". No pátio, "parece que o tempo não passa, parece que o tempo fica parado", resume um dos jovens. Mas, ao lado da necessidade de "matar o tempo", surgia, com o início da prática musical, um "gostar" pouco entendido pelos próprios meninos:

Ele fazia aula comigo e um dia me perguntou: 'Professora, por que eu não consigo parar de pensar no violoncelo?'. Respondi que era porque ele estava gostando de aprender. Para eles, não era muito normal gostar de alguma coisa (Luciana Rosa, professora de violoncelo e contrabaixo no pólo Febem).

Dawsey (1998:37-38) propõe que invertamos a proposição de Geertz de transformar o exótico em familiar. Sugere que, com Brecht, mostremos que o "lugar familiar" é, na verdade, um "lugar distante", estranho. Apontar o familiar como exótico seria o primeiro passo para provocar o efeito de distanciamento, base didática do teatro de Brecht. Somente com essa inversão é possível entender a situação acima descrita. Ao aluno, interno na Febem, gostar de alguma coisa (algo familiar para nós) é muito estranho, quase incompreensível. À professora, o estranhamento do aluno causou espanto - tanto que a levou a me narrar o fato. Cabe notar que, à época, eu também era sua aluna, e gostar de um instrumento ou de música era para mim algo completamente "natural". Assim, em vários níveis, a música provocou a interrupção necessária para qualquer processo reflexivo.

"Comecei a tocar só para sair da unidade, mas agora eu estou gostando mesmo". A frase, comum entre os internos participantes do Guri na Febem, ecoa o exemplo anterior. Nesta instituição, presenciei aulas de até quatro horas de duração, com grupos de 10 a 15 adolescentes iniciantes em um instrumento de orquestra, que permaneciam, durante todo esse tempo, concentrados, atentos à partitura, trocando informações e dúvidas, mesmo enquanto o professor se ausentava da sala. Diante de tal cenário, não é possível aceitar o desejo de "matar o tempo" como justificativa para a participação no projeto. 
Conhecendo as peculiaridades do estudo musical — que é repetitivo, envolve resistência física e psicológica, não apresenta resultados imediatos - eu sabia que quatro horas de aula de viola ou violino poderiam ser tão longas quanto as horas no pátio, caso não houvesse um real interesse na atividade. $\mathrm{O}$ que observei, entretanto, foi um grupo de jovens experimentando aquilo que fazer música em grupo proporcionava: sentimento de conjunto, concentração, cooperação, comunicação, superação de dificuldades, autoconfiança, prazer. O tempo não estava sendo "morto", mas vivido intensamente.

Estas características do fazer musical são extensíveis à prática musical em grupo, em geral. A especificidade do pólo Febem está justamente na maneira como se dá o trânsito entre o "passatempo" e o "gostar mesmo" na prática musical. Há, na vida institucional, o peso insuportável do ócio vigiado. Esse tempo, é preciso "matar". A música é acionada para tal. Mas não somente: o que diferencia a prática musical no pólo Febem é que ela instaura conhecimento e desejo em corpos sem liberdade.

A prática musical demanda uma preparação muito específica do corpo. É preciso aquecê-lo para a música. Alongamentos podem ser realizados nessa preparação. Tensões são indesejáveis tanto para a prática do canto quanto para a de um instrumento. É preciso estar relaxado. É impossível fazer música - sobretudo em grupo - sem muita concentração e sintonia entre os músicos. É necessário estar disposto para lançar corpo e mente em uma sessão de uma ou várias horas de estudo musical.

Na Febem, durante as aulas ou ensaios do Guri, a relação dos internos com regras, ritmos e obrigações institucionais passavam por mudanças significativas: nas aulas, os jovens não eram "vigiados" por monitores; sentavam-se ou levantavam-se de acordo com sua vontade ou com a necessidade imposta pela atividade.Eram freqüentemente levados a observar seu corpo, sua postura, suas tensões. Nesses momentos, evidenciava-se o conflito entre o corpo do interno e o corpo para a música. Por vezes, ouvi os jovens comentarem com seus professores que estavam "quebrados". Pode-se pensar que o corpo "quebra" não somente quando castigos corporais — ainda comuns na Febem — são aplicados, mas também quando os seus movimentos são tolhidos. As posturas obrigatórias - cabeça baixa, mãos para trás, andar ritmado - marcam o corpo do interno, ao restringir seu repertório de movimentos à coreografia da submissão. A música introduz elementos dissonantes nessa coreografia. Solicita leveza, força, delicadeza, relaxamento. A experiência musical acorda os sentidos, "faz esquentar o sangue".

"Por que você decidiu aprender violino?" - perguntei a um jovem interno. "A senhora já viu um desses aqui na rua?" - retrucou. O trecho de conversa é significativo. Sempre que expus o conteúdo do projeto que 
eu analisava nesta pesquisa, fui questionada sobre o porquê de se ensinar instrumentos de orquestra, repertório erudito, para jovens que nunca tiveram - nem viriam a ter - contato com este universo. Tentativa civilizatória, diriam alguns; aculturadora, outros. A fala do jovem revela, no entanto, uma apropriação diversa do conteúdo oferecido. Para aquele menino, não interessava aprender cavaquinho ou violão - também oferecidos pelo Guri, no pólo Febem. Esses instrumentos, ele conhecia da rua, das rodas da vizinhança. A oportunidade de aprender violino era, para ele, uma forma de acesso a um conhecimento exclusivo, que lhe interessava porque diverso do que ele acessava na rua. Era, no limite, uma forma de diferenciação tanto no interior da Febem quanto no "mundão".

Fazer música pode corresponder, portanto, à afirmação de uma diferença. Jovens presos estudando violino constituem uma imagem que se destaca, causando até mesmo reações adversas dentro e fora da Febem. De um funcionário da Febem, por exemplo, ouvi um longo discurso sobre a importância da profissionalização (por meio dos cursos de capacitação) do jovem interno para sua readaptação à sociedade e uma frase curta e grossa sobre o Guri: "isso é ilusão!". Comentário que não se distancia do raciocínio de uma senhora indignada com a "inutilidade" do ensino musical para "bandidos": "tem que ensinar a trabalhar!".

Alba Zaluar (1994), em uma pesquisa sobre projetos de prática esportiva com jovens de escolas públicas nos anos 80, comentou a tendência de classificação do esporte como atividade elitista, já que associada ao lazer e ao ócio. O ócio - e sua associação com o lazer, o esporte e as artes - é "permitido às classes abastadas"19, mas o acesso aos bens culturais e artísticos não é visto ainda como direito de todo cidadão, apesar de garantido legalmente em nosso país.

Uma inversão neste cenário se dá quando, nos mais diversos contextos — na Febem, na periferia ou nos bairros nobres da capital — surge a necessidade de ocupação do tempo ocioso, que passa a ser visto como um potencial estimulador da desordem (da rebelião, na Febem; do ingresso no universo do crime, das drogas, nas ruas da cidade). Ninguém questionaria a decisão de uma família de classe média de matricular seu filho em uma escola de música - este aprendizado faz parte, historicamente, da formação das crianças e jovens das famílias burguesas - mas o ensino de música para crianças pobres, para jovens "presos", causa estranhamento e até repulsa. Quando a música é tocada em instrumentos de orquestra — pouco acessíveis até para as classes mais abastadas - o estranhamento é ainda maior.

Na Febem, as diferenças explodem. A música sobrepõe a lógica do tempo livre — não liberado - à do tempo institucional (tempo do preso). Nesse 
sentido, pode ser subversiva ${ }^{20}$. Oferecida a "menores infratores", põe em risco a ordem que separa os universos do trabalho e do lazer, da punição e da diversão, de presos e libertos, do popular e do erudito, de pobres e ricos.

\section{Coda}

As observações acerca do aprendizado musical entre jovens em situação de internação foram trazidas para iluminar algumas reflexões mais gerais sobre a relação entre as temporalidades do fazer musical e a dos grupos de crianças e jovens que pesquisei. O movimento desta pesquisa se dá entre a percepção da música como ação ocupacional, boa para "matar o tempo", e sua descoberta como algo que preenche e atribui sentido à vida. Isto porque a música, chamada a ocupar o "tempo ocioso", atua suprimindo o fluxo do tempo, como lembra Lévi-Strauss (1991), jogando seus praticantes em outro fluxo marcado, como notou Huizinga (2000:16), pela experiência da imersão, que os envolve de maneira "intensa e total". A imersão e o envolvimento proporcionados pelo fazer musical, característicos do jogo, dos momentos liminares (analisados por Turner), não são experiências que se encerram na ocupação do tempo ocioso; transbordam para outros momentos da vida, repercutem na organização das subjetividades dos jovens estudantes de música. A música, antes intervalo, contamina a vida cotidiana, determinando ritmos, preenchendo vazios, construindo sentidos.

Recebido em 24 de outubro de 2004

Aprovado em 22 de novembro de 2005

Rose Satiko Gitirana Hikiji é professora do Departamento de Antropologia da Universidade de São Paulo. E-mail: <satiko@usp.br>

\section{Notas}

${ }^{1}$ Em meu doutorado (Hikiji, no prelo), analisei os sentidos da prática musical entre crianças e jovens participantes do Projeto Guri. O Guri teve início em 1995 e contava, em 2005, com 101 pólos, atendendo cerca de 22 mil crianças em todo o estado. Oferece aulas de violino, viola, violoncelo, baixo acústico, violão, cavaquinho, 
percussão, saxofone, clarinete, flauta, trompete, trombone e canto coral. A pesquisa teve o apoio da Fapesp, instituição à qual agradeço.

${ }^{2}$ A teoria musical ocidental relaciona intensidade, altura e timbre como suas outras propriedades.

${ }^{3}$ José Miguel Wisnik também afirma a relação dupla da música com o tempo, ressaltando, porém, a relação consciente-inconsciente: "Desiguais e pulsantes, os sons nos remetem no seu vai-e-vem ao tempo sucessivo e linear mas também a um outro tempo ausente, virtual, espiral, circular ou informe e, em todo caso, não cronológico, que sugere um contraponto entre o tempo da consciência e o não-tempo do inconsciente" (1999:28).

4 "Concerto grosso" é um tipo de concerto identificado com o período barroco, que consiste na alternância entre um pequeno grupo de instrumentos e toda a orquestra. Os trechos nos quais tocam juntos todos os instrumentos da orquestra resultam em grande sonoridade e, em certo sentido, "peso".

${ }^{5}$ 1999, ano em que iniciei a pesquisa de campo no pólo Febem do Projeto Guri, foi também o ano de algumas das maiores e mais violentas rebeliões da história da instituição. No dia 3 de setembro de 1999, 64 internos fugiram da Febem Tatuapé. Onze dias depois, mais 37 adolescentes conseguiram fugir. Em 23 de outubro, teve início uma crise que durou três dias: mais de 1.000 dos quase 1.300 internos se rebelaram, tomando conta da unidade Imigrantes. Prédios foram incendiados, monitores e internos foram mantidos reféns por jovens rebelados. Internos foram espancados e quatro deles foram mortos - um, decepado; dois, carbonizados. Em novembro de 1999, a unidade Imigrantes foi demolida. Um grande número de meninos foi transferido para instituições do sistema carcerário (cf. Miraglia 2001).

${ }^{6}$ Pensa-se aqui na diminuição das horas trabalhadas por dia, no processo que vai da Revolução Industrial - quando até as crianças não trabalhavam menos do que 15 horas por dia - até os anos 20, quando começam a surgir, em alguns países, as jornadas de oito horas e a semana de cinco dias (Waichman 2001:33-34).

${ }^{7}$ Analiso a construção da categoria "situação de risco" e as discussões acerca da infanto-adolescência no Brasil, no segundo capítulo de minha tese (Hikiji, no prelo). Discuto também neste capítulo o crescimento da oferta de projetos sociais que propõem a arte-educação como meio de intervenção em comunidades de jovens de baixa renda. A Agência de Notícias dos Direitos da Infância (Andi) dispõe em seu site (www.andi. org.br) de um banco de projetos sociais (hoje, "Banco de fontes") dividido em áreas de atuação. Em 2002, na área "Arte e Cultura", eram apresentados cerca de duzentos projetos de organizações da sociedade civil, provenientes de todo o país, com foco em atividades relacionadas à arte-educação, destinadas a comunidades de baixa renda, sobretudo crianças e jovens. No mesmo site, eram listadas mais de trinta entidades governamentais e mais de quarenta empresas, fundações ou institutos que também mantêm projetos com atividades artísticas direcionadas a públicos com algum nível de carência. Nas apresentações desses projetos, o público-alvo é constantemente de- 
finido como "jovens em situação de risco" (ou por variantes: "risco social ou pessoal", "jovens carentes", "comunidades menos favorecidas", "população excluída"). Nos objetivos, destacam-se as possibilidades de, por meio da arte, se promover cidadania, integração social, sociabilização, desenvolvimento da auto-estima, além de "tirar as crianças das ruas" e "ampliar o universo cultural".

${ }^{8}$ Alessandra Cristina Raimundo, aluna do Guri no pólo Mazzaropi desde a sua fundação, descreveu da seguinte forma sua experiência em uma das orquestras do Projeto: "Na [orquestra] Paulista, tem gente do pólo de Santos, do Mazzaropi, de Indaiatuba. Antes eu pensava: 'nossa família é o Mazzaropi', agora penso que podemos formar outras famílias. A relação que criamos é tipo uma família". O fato de Alessandra destacar a sociabilidade como um dos fatores principais do Guri, e fazê-lo por meio da metáfora da "família", indica a centralidade dessa imagem para o fazer musical neste projeto.

${ }^{9}$ O processo de gravação do rap com os jovens internos é apresentado no vídeo Microfone, senhora (LISA, NTSC, cor, 16 min, 2003), parte integrante de minha tese, disponível no Laboratório de Imagem e Som em Antropologia da USP (LISA/USP: www.lisa.usp.br).

${ }^{10}$ POF e São Remo são pólos instalados em favelas, com atividades destinadas às comunidades locais. O Mazzaropi, por sua tradição (é o mais antigo) e localização (próximo à estação Belém do Metrô), recebe alunos da região central de São Paulo, mas também das zonas leste, oeste, norte e até de cidades vizinhas, como Guarulhos.

${ }^{11}$ Boa parte dos grupos de rappers se organiza em "posses": "A posse integra número variado de grupos e busca ações mais estruturadas", tem caráter político e preocupação com aspectos organizativos (Sposito 1994:170).

${ }^{12}$ Em alguns pólos, e mesmo na Febem, houve períodos em que era possível levar o instrumento do Guri para casa, ou para a Unidade Educacional, no caso dos internos. Essas iniciativas não foram mantidas na maioria dos pólos, segundo a coordenação, por motivos de preservação dos instrumentos.

13 "Um performer de kathakali, um bailarino, um ator do teatro Nô, cada um possui modos específicos de movimento, de sonoridade e, eu diria, de ser: são pessoas marcadas" (Schechner 1995:257, tradução minha). Cabe notar que uso aqui "performance" no lugar de "playing", no original de Schechner. Em inglês, play pode ser traduzido por jogo, atuação, execução instrumental etc. O autor ora fala da atuação teatral, ora de outros tipos de performances, como a musical, por exemplo.

${ }^{14}$ Entre os motivos da interrupção, a coordenação do projeto elencou: a reestruturação da Febem ("com a última rebelião, estão descentralizando e pedindo para atendermos nessas novas unidades [as prisões]"); a passagem das aulas para o interior das unidades ("dentro das unidades, é a casa deles. Na casa deles, tem aquele que se interessa pelo estudo e o que não se interessa"); a superlotação e o perfil dos internos ("como a Febem não atende mais carente, e sim circuito grave, na verdade, não são 
mais meninos, são homens. Mudou a característica deles: muito mais violentos, rudes."). Cabe notar que a justificativa da mudança no perfil (de "carente" para "circuito grave") é, em parte, equivocada. A Febem Tatuapé manteve, até 1999, uma única unidade para menores abandonados, fechada em seguida. O público atingido pelo Guri na Febem sempre foi o de jovens em conflito com a lei. Por outro lado, em 2003, ouvi da coordenação de Projetos Especiais da Febem o mesmo argumento da mudança do perfil do jovem interno. A coordenadora não falava, obviamente, em "carentes" versus "circuito grave", mas comentava que as internações, no período anterior, motivadas pela prática de pequenos furtos e roubos, agora se deviam à inserção cada vez maior dos jovens nos quadros do crime organizado (a referência temporal da entrevistada era o período em que eu realizei a pesquisa na Febem - sobretudo 1999 - e o ano de 2003). O argumento da coordenação da Febem não diferia, em conteúdo, do da coordenação do Guri: os jovens estariam de fato mais violentos, o que dificultaria, na opinião das mesmas coordenadoras, o desenvolvimento de atividades especiais como, por exemplo, o Guri. Infelizmente, tal percepção vem sendo usada também para justificar ações mais violentas - tratamento dispensado ao jovem internado em total desacordo com o ECA (Estatuto da Criança e do Adolescente) - e o movimento pela diminuição da idade penal.

${ }^{15}$ A experiência corresponde ao que Foucault (1988:114) descreveu como a punição por meio da imposição institucional da rotina: "horários, distribuição do tempo, movimentos obrigatórios, atividades regulares, meditação solitária, trabalho em comum, silêncio, aplicação, respeito, bons hábitos". Estes são os instrumentos que têm por fim não a correção do "sujeito de direito, que se encontra preso em razão dos interesses fundamentais do pacto social", mas a constituição do "sujeito obediente, o indivíduo sujeito a hábitos, regras, ordens, uma autoridade que se exerce continuamente sobre ele e em torno dele, e que ele deve deixar funcionar automaticamente nele".

${ }^{16}$ Erving Goffman, em sua análise sobre as instituições totais, afirma que a obrigação de pedir permissão para a realização de atividades que a pessoa pode executar sozinha no mundo externo, como as descritas no caso da Febem (fumar, ir ao banheiro etc.), constitui "uma das formas mais eficientes para perturbar a 'economia' de ação de uma pessoa" (1974:44). Submissão e humilhação são os resultados mais evidentes desse processo de pormenorização e controle da rotina.

${ }^{17}$ Em Hikiji e Miraglia (2000), discutimos mais detidamente a temporalidade da internação e a situação da Febem.

${ }^{18}$ O Estatuto da Criança e do Adolescente determina que a internação deve ser por "tempo indeterminado", desde que respeitado o mínimo de seis meses e o máximo de três anos. Com isso, o ECA pretende proteger o jovem de receber uma "pena", nos moldes da justiça comum, determinando ainda que os processos sejam reavaliados periodicamente pelo juiz, que pode apressar ou não a medida de desinternação. O problema é que os internos não possuem clareza sobre essa dinâmica, e interpretam o "tempo indeterminado" como a pena em si. Essa interpretação, associada à desinformação, é uma das principais fontes da angústia do jovem. Muitos 
MÚSICA PARA MATAR O TEMPO - INTERVALO, SUSPENSÃO E IMERSÃO

deles, prestes a serem desinternados, tentam fugir (algumas vezes, com sucesso), o que coloca em risco sua integridade física, bem como sua situação legal futura (cf. Hikiji e Miraglia, 2000).

19 Classes abastadas que também são chamadas "ociosas e cuja marca de distinção é a relação desinteressada e não utilitária com as artes, o esporte e outras atividades distanciadas do mundo do trabalho" (Zaluar 1994:59).

${ }^{20}$ Turner afirmou o potencial subversivo das atividades liminóides. Ao contrário dos processos liminares (aqui, refere-se aos mitos e ritos, que também chama de gêneros "sérios" da ação simbólica), implicados em visões cíclicas repetitivas do processo social, os gêneros liminóides, embora menos sérios aos olhos da comunidade, têm grande potencial para mudar os modos pelos quais os homens se relacionam uns com os outros (Turner 1974).

\section{Referências bibliográficas}

BARENBOIM, Daniel e SAID, Edward. 2003. Paralelos e paradoxos. Reflexões sobre música e sociedade. São Paulo: Companhia das Letras.

CARNEIRO DA CUNHA, Manuela e VIVEIROS DE CASTRO, Eduardo. 1985. "Vingança e temporalidade: os Tupinambás". Journal de la Societé des Americanistes, LXXI:191-208.

DAMATTA, Roberto. 1991. A casa \& a rua. Rio de Janeiro: Guanabara.

DAWSEY, John Cowart. 1998. De que riem os "bóias-frias"? Walter Benjamin e o teatro épico de Brecht em carrocerias de caminhões. Tese de livre-docência, FFLCH/USP.

FOUCAULT, Michel. 1988. Vigiar e punir. História da violência nas prisões. Rio de Janeiro: Vozes.

GEERTZ, Clifford. 1983. Local knowledge. Nova Iorque: Basic Books.

GOFFMAN, Erving. 1974. Manicômios, prisões e conventos. São Paulo: Perspectiva.
GOIFFMAN, Kiko. 1998. Valetes em slow motion. Campinas: Editora da Unicamp.

GUASCO, Pedro Paulo M. 2001. Num país chamado periferia: identidade e representação da realidade entre os rappers de São Paulo. Dissertação de mestrado, PPGAS-USP.

HIKIJI, Rose Satiko Gitirana. no prelo. A música e o risco. Etnografia da performance de crianças e jovens participantes de um projeto social de ensino musical. São Paulo: Edusp/ Fapesp.

e MIRAGLIA, Paula. 2000

"'Peguei tempo indeterminado': vigilância, violência e revolta entre os muros da Febem". Sexta Feira - Antropologia, Artes, Humanidades, 5:50-60.

HUIZINGA, Johan. 2000. Homo ludens. O jogo como elemento da cultura. São Paulo: Perspectiva.

JOURDAIN, Robert. 1998. Música, cére- 
bro e êxtase. Como a música captura nossa imaginação. Rio de Janeiro: Editora Objetiva.

LÉVI-STRAUSS, Claude. s/d. Antropologia estrutural. Rio de Janeiro: Tempo Brasileiro.

. 1991. O cru e o cozido. São Paulo: Brasiliense.

MAGNANI, José Guilherme Cantor. 1992. "Da periferia ao centro: pedaços \& trajetos". Revista de Antropologia, 35:191-203.

MANN, Thomas. 1980. A montanha mágica. Rio de Janeiro: Nova Fronteira.

MIRAGLIA, Paula. 2001. Rituais da violência. A Febem como espaço do medo em São Paulo. Dissertação de Mestrado, PPGAS-USP.

MIRANDA, Dilmar Santos de. 2001. Tempo da festa $\mathrm{x}$ tempo do trabalho. Transgressão e carnavalização na Belle Époque tropical. Tese de doutoramento em sociologia, USP.

SCHECHNER, Richard. 1995. The future of ritual. Writings on culture and performance. Londres e Nova Iorque: Routledge.

SILVA, Franklin Leopoldo. 2000. "Tempo: realidade e símbolo". Sexta feira - Antropologia, Artes, Humanidades, 5:81-88.

SPOSITO, Marilia Pontes. 1993. "A sociabilidade juvenil e a rua: novos conflitos e ação coletiva na cidade". Tempo Social , 5(1-2):161-78.

TURNER, Victor. 1974. Dramas, fields and metaphors. Symbolic action in human society. Ithaca e Londres: Cornell University Press.

TURNER, Victor. 1982. From ritual to theatre. The human seriousness of play. Nova Iorque: PAJ Publications.

WAICHMAN, Pablo. 2001. Tempo livre e recreação: um desafio pedagógico. Campinas: Papirus.

WISNIK, José Miguel. 1999. O som e o sentido. Uma outra história das músicas. São Paulo: Companhia das Letras.

ZALUAR, Alba. 1994. Cidadãos não vão ao paraíso. Campinas: Edunicamp.

\section{Filmografia}

HIKIJI, Rose Satiko (direção e co-edição) e PUZZO, Gianni (edição). 2003. Microfone, senhora. São Paulo: Laboratório de Imagem e Som em Antropologia da USP (LISA)/ Fapesp, NTSC, cor, 16'. 
Resumo

Discuto neste artigo algumas relações da música com o tempo, em especial a relação entre as temporalidades dos grupos de crianças e jovens que pesquisei e certas propriedades do tempo da prática musical. Na pesquisa com alunos de um projeto governamental de ensino musical (Projeto Guri/ São Paulo), ouvi como principal justificativa para a procura pela música, a necessidade de "matar o tempo". Na perspectiva do senso comum, o tempo "ocioso" é um tempo perigoso. Para pais e proponentes, é preciso "ocupar o tempo" das crianças e jovens, é preciso "tirá-los da rua". Analiso aqui o processo de atribuição de valor negativo ao tempo livre e a especificidade do tempo do fazer musical. Aproximo o tempo musical do tempo do jogo, caracterizado pela imersão e pela suspensão do cotidiano. Analiso, finalmente, como o tempo para a música, inicialmente um intervalo, transborda para o resto da vida cotidiana, determinando ritmos, preenchendo vazios, construindo sentidos.

Palavras-chave: Temporalidade, Música, Infância e Juventude, Tempo Livre, Febem

\section{Abstract}

This article discusses some of the relations between music and time, in particular the temporalities of groups of children and youths I have researched, and certain properties of music making time. In my research with students from a government musical education project (Guri Project/ São Paulo), the main reason given for studying music was their need to 'kill time.' From a common sense point of view, 'idle' time is dangerous time. Parents and project organizers stress the need 'to occupy the time' of children and youths, 'to take them off of the streets.' Here I analyze the negative evaluation of free time and the specificity of music making time. Musical time is compared with play time, characterized by an immersion in the activity and by the suspension of daily life. Finally, I ask how the time for music, initially an interval, overflows into the rest of the daily life, determining rhythms, filling empty spaces and building meanings.

Key words: Temporality, Music, Childhood and Youth, Free Time, FEBEM 